\title{
Polycomb Protein Scm
}

National Cancer Institute

\section{Source}

National Cancer Institute. Polycomb Protein Scm. NCI Thesaurus. Code C19870.

Polycomb protein Scm (877 aa, $294 \mathrm{kDa}$ ) is encoded by the Drosophila Scm gene. This protein is part of a complex that is required to maintain the transcriptionally repressive state of homeotic genes throughout development. 